\title{
DIMINISHED IL-2-INDUCED GAMMA-INTERFERON PRODUCTION BY UNSTIMULATED PERIPHERAL- BLOOD LYMPHOCYTES IN RHEUMATOID ARTHRITIS
}

\author{
BY F. HASLER AND J-M. DAYER \\ Rheumatology Division, Inselspital Berne and Immunology and Allergy Division, \\ Department of Medicine, University Hospital Geneva, Switzerland
}

\begin{abstract}
SUMMARY
A diminished gamma-interferon (IFN-gamma) production by $T$ cells from patients with rheumatoid arthritis (RA) in response to autologous stimulation coincides with a defective regulation of Epstein-Barr virus (EBV) transformation and is in part due to monocyte-produced interleukin-1 (IL-1) inhibitor and prostaglandins. Since IL-2 can act directly on unstimulated T-cells to induce IFN-gamma production we have now examined the effect of recombinant IL-2 (rIL-2) on purified resting T lymphocytes from RA patients. Treatment with rIL-2 $(25 \mathrm{U} / \mathrm{ml})$ of lymphocytes from 15 controls led to an increased production of 72-h supernatant EBV-inhibitory activity ( $19 \pm 4 \%$ SE without; $48 \pm 7 \%$ with rIL-2), but had only minimal or no effect on gamma-interferon production by E-rosetting lymphocytes from 15 patients with active RA. This defect could not be corrected by adding indomethacin to RA cultures.
\end{abstract}

KEY wORDS: Rheumatoid arthritis, Interleukin-2, Gamma interferon, Epstein-Barr virus.

RHEUMATold arthritis (RA) is associated with subtle immunoregulatory defects that can be in part recognized in the deficient autologous mixed leucocyte reaction (AMLR) [1-3] and in the in vitro and in vivo abnormalities relating to Epstein-Barr virus (EBV) infection [3-10]. We have previously presented evidence that a diminished gamma-interferon (IFN-gamma) production by RA $T$ lymphocytes coincides with a defect of the suppression of the EBV-induced DNA-synthesis [3]. The suppression of EBVinduced $B$ cell proliferation by AMLR-supernatants can be blocked with monoclonal antibody against IFN-gamma which indicates that this assay can be used for detecting small amounts of IFN-gamma [3]. The impaired IFN-gamma production is observed when the RA T cells interact with autologous non- $T$ lymphocytes and may be due in part to prostaglandin and IL-1 inhibitor produced by the adherent cell population $[8,9]$. In contrast, when activated by monocytedepleted AMLR stimulator cells, the RA T lymphocytes can then produce IFN-gamma in normal amounts $[8,9]$. AMLR proliferative response and IFN-gamma generation are significantly associated with the production of IL-2 [1, $9,11-13]$, which may itself be modulated by monocyte-mediated events $[9,14,15]$. IL-2 can also act directly on unstimulated $T$ cells to induce IFN-gamma production without induc-

Submitted 6 February; revised version accepted 20 May 1987.

Address correspondence to Dr. F. Hasler. tion of a mitogenic response [12]. In different assay systems, RA lymphocytes produced less IL-2 than normals and responded poorly to exogenous IL-2 $[1,16,17]$. This study was undertaken to examine the effect of rIL-2 on RA T lymphocytes in the absence of mitogens or AMLR stimulator cells.

\section{Subjects}

\section{MATERIALS AND METHODS}

Heparinized venous blood was obtained from 15 patients with definite or classical active RA, aged 39-75 (mean 58) years [18]. The control population consisted of 12 normal blood-donors aged $27-76$ (mean 45 ) years. Three patients with active seronegative spondarthropathies all taking nonsteroidal anti-inflammatory drugs (NSAIDs) (two with psoriasis and polyarticular arthritis, one with ankylosing spondylitis, aged 44,76 and 18 years) were added to the healthy control group. All of the RA patients were taking NSAIDs and, in addition, 11 of the RA patients were receiving either chloroquine, gold or D-penicillamine. Two RA patients were also being treated with small doses $(<10 \mathrm{mg} / \mathrm{d})$ of prednisone.

\section{Cell separation}

Peripheral-blood mononuclear cells (PBM) were obtained from heparinized venous blood by Ficoll-Hypaque density-gradient centrifugation, and E-rosetting lymphocytes were separated from non-T cells by erythrocyte-rosetting with 2-aminoethylisothiouronium hydro- 
bromide (AET, Sigma, St. Louis, MO) treated sheep red blood cells [19]. PBM were depleted of adherent cells by passage through G-10 Sephadex columns [20] in RPMI 1640 supplemented with $10 \%$ heat-inactivated FCS. The resultant $\mathrm{E}+$ cell population contained $>90 \%$ E-rosetting cells and less than $2 \%$ esterase positive cells.

\section{Peripheral blood mononuclear cell proliferative responses}

Adherent cell-depleted lymphocytes were cultured in $0.2 \mathrm{ml}$ RPMI $1640-10 \%$ FCS supplemented with $2 \mathrm{mM}$ glutamine and gentamycin $(10 \mu \mathrm{g} / \mathrm{ml})$ in 96-well flat-bottomed Linbro plates (Flow Laboratories, Hamden, $\mathrm{CT}$ ) in the presence or absence of recombinant IL-2 (gift from Biogen S.A., Geneva). Cells were pulsed with $(3 \mathrm{H})$ thymidine $(1 \mu \mathrm{Ci} /$ well; sp.act. $5 \mathrm{Ci} / \mathrm{mmol}$, Amersham Corp.) for the last $18 \mathrm{~h}$ of incubation. The cultures were harvested on day 3 with a semi-automated multiple-sample harvester (MASH) device. Data are expressed in $\mathrm{cpm} \pm \operatorname{SEM}(n=4)$.

\section{Preparation of supernatants}

$T$ cell derived supernatants were produced in the presence and absence of rIL-2 $(25 \mathrm{U} / \mathrm{ml})$ in $2 \mathrm{ml}$ RPMI-10\% FCS at a cell density of $10^{6}$ cells $/ \mathrm{ml}$. After $72 \mathrm{~h}$, the supernatants were recovered and filtered through $0.45 \mu \mathrm{m}$ membranes (Millipore Corp., Bedford, MA). The supernatants were stored at $-70^{\circ} \mathrm{C}$ until used.

\section{EBV and interferon assay}

Transforming virus was obtained from the supernatants of the EBV-secreting B 95-8 marmoset lymphoblastoid cell line. Double-rosetted normal non-T cells were infected with EBV, and the effect of 72-h culture supernatants on EBVinduced DNA synthesis was assessed by measuring $(3 \mathrm{H})$ thymidine incorporation on day 10 as described [3]. The data obtained are expressed as percentage suppression calculated as:

$$
\left[1-\frac{(\mathrm{cpm} \text { in supernatant-treated cultures })}{\text { (cpm in control cultures })}\right] \times 100 .
$$

Gamma-interferon was measured using a radioimmunoassay (Centocor, Malvern, PA) [21].

\section{Prostaglandin and IL-2 assay}

Culture fluids were assayed for $\mathrm{PGE}_{2}$ and for IL-2 as previously described [22].
Monoclonal anti-Tac antibody and control ascites was provided by T. A. Waldmann, NIH [23].

Student's $t$ test was used to determine the significance of differences between groups.

\section{RESULTS}

In the presence of rIL-2, unstimulated E-rosetting lymphocytes from 15 controls released factor(s) into the culture medium which suppressed EBV-induced DNA synthesis as an index of IFN-gamma production (Fig. 1). EBVinduced $B$ cell proliferation, measured 10 days after virus infection, was inhibited by 72 -h cul-

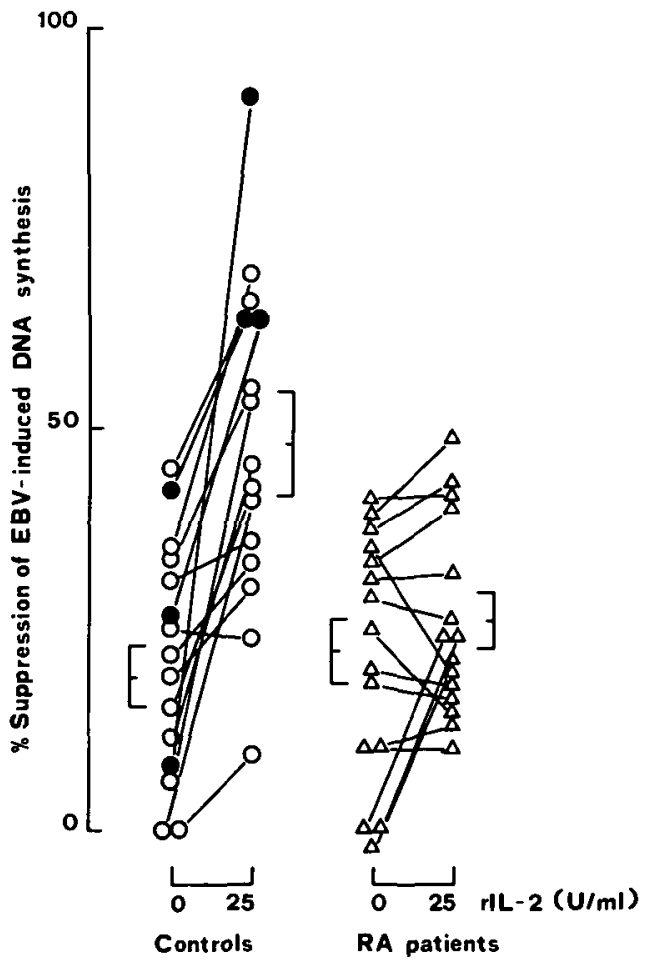

Fig. 1.-The effect of rIL-2 on the production of a supernatant inhibitory factor by $E$-rosetting lymphocytes. $2 \times 10^{6} \mathrm{~T}$ cells from 12 normal controls $(\mathrm{O})$, three patients with seronegative spondarthropathies (O) and $15 \mathrm{RA}$ patients were incubated in $0.2 \mathrm{mI} \mathrm{RPMI} 1640-10 \%$ FCS in the presence and absence of rIL-2 $(25 \mathrm{U} / \mathrm{ml})$. Supernatants collected at $72 \mathrm{~h}$ were tested for their ability to suppress EBV-induced DNA synthesis. The results are expressed as the mean perecntage suppression of $(3 \mathrm{H})$ thymidine incorporation compared with control cultures at 10 days post EBV infection (mean control counts from six experiments $=67811 \mathrm{cpm}$ ). Error bars represent the mcan $\pm S E M$ for all individuals in the designated groups. 
ture supernatants from $19.2 \% \pm 4.0$ (mean \pm SE) without rIL-2 to $47.8 \% \pm 6.5$ at an rIL-2 concentration of $25 \mathrm{U} / \mathrm{ml}(\mathrm{p}<0.001)$. R IL-2 had no direct inhibitory effect on EBV-induced B lymphoblast transformation. Tested on three occasions at 4-week intervals, the IL-2-induced IFN-gamma response from the same normal donor (E.F.) was similar. Three patients with active seronegative spondarthropathies treated with NSAIDs responded similarly to normal donors. In contrast to the inhibitory activity on EBV-induced DNA synthesis generated by $T$ lymphocytes from controls in response to rIL-2, the E-rosetting lymphocytes from 15 RA patients did not generate this inhibitory activity in response to ILL-2.

To confirm that the EBV inhibitory factor was specifically induced by rIL-2, a monoclonal antibody against IL- 2 receptor was added at a final concentration of 1:2000 to the culture of a normal donor. At the two concentrations of rIL-2 tested, Tac antibody abrogated completely the induction of interferon (Fig. 2). Tac antibody

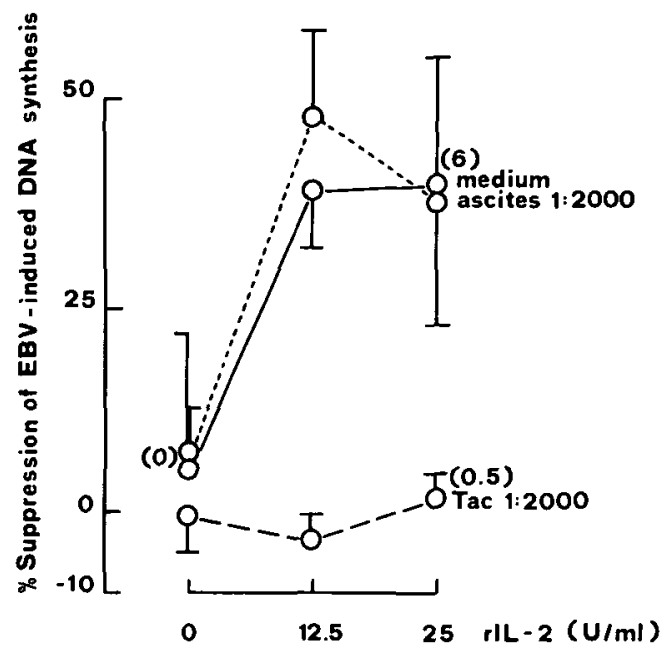

Fig. 2.-The effect of Tac monoclonal antibody on the production of a supernatant inhıbitory factor by E-rosetting lymphocytes from a normal control stimulated with rIL-2. E-rosetting cells were exposed to rlL-2 in absence $(\longrightarrow$ ) or presence of control ascites at 1:2000 (- - ) for $72 \mathrm{~h}$. Tac antibody was added to the cell cultures prior to the addition of rlL-2 at a final concentration of 1:2000 (- -). Supcrnatants collected at $72 \mathrm{~h}$ were tested for their ability to suppress EBV-induced DNA synthesis. Results are indicated as the SEM of quadruplicate culture. Numbers in brackets represent $\mathrm{U} / \mathrm{ml}$ of IFN-gamma measured by radio-immunoassay as described in Materials and Methods. and control ascites had no significant direct effect on EBV-induced proliferation.

Since a small quantity of adherent cells (judged by esterase staining) always contaminated our cultures $(<2 \%)$ and since prostaglandins produced by these adherent cells can decrease IFN-gamma generation, indomethacin $(1 \mu \mathrm{g} / \mathrm{ml})$ was added to the cell cultures. PGE concentration in non-indomethacin-treated cultures was $<4 \mathrm{ng} / \mathrm{ml}$ and indomethacin did not affect interferon activity of supernatants (three of three experiments with RA cells, data not shown).

A difference in subsets of lymphocytes or spontaneous IL-2 release due to separation techniques or disease might contribute to the RA defect. To test this possibility, lymphocytes were examined for surface phenotypes and the corresponding cell-culture supernatants, stimulated or unstimulated with rIL-2, were examined for EBV-suppressive activity. In two of two experiments, both rIL-2 responding controls and nonresponding RA patients showed similar ratios of OKT3, OKT4 and OKT8 subpopulations (data not shown). IL-2 concentration in unstimulated 72-h $\mathrm{T}$ cell supernatants from three control and three RA cultures was $<0.01 \mathrm{U} / \mathrm{ml}$.

A difference in supernatant EBV inhibitory activity might be paralleled by a difference in the proliferation of the control and RA lymphocytes exposed to rIL-2. As shown in Table I, $(3 \mathrm{H})$ thymidine incorporation on day 3 by purified $T$ lymphocytes was no different in normal and RA cells in the presence or absence of rIL-2.

Using a radio-immunoassay (Centocor IFN. gamma RIA), when the supernatant EBV inhibitory activity was high, gamma-interferon level paralleled the percentage suppression of EBV-induced DNA synthesis (Table II). rIL2-induced IFN-gamma production by normal cells could be inhibited by the addition of Tac antibody (Fig. 2) and no IFN-gamma was found in non-EBV-inhibitory RA T cell supernatants (Table II).

\section{DISCUSSION}

We have confirmed that peripheral-blood $\mathrm{T}$ lymphocytes from RA patients are deficient in their response to IL-2 $[1,16,17]$. We have shown that unstimulated $T$ cells from normal controls and patients with spondarthropathies in the presence of rIL-2 produce sufficient amounts of gamma-interferon to inhibit in vitro EBV. induced $B$ cell proliferation. By contrast, RA E-rosetting lymphocytes are deficient in their 
TABLE I

Proliferative Response of E-rosetting Lymphocytes*

\begin{tabular}{|c|c|c|c|c|c|c|}
\hline \multirow[b]{2}{*}{ Donor } & \multicolumn{3}{|c|}{ Controls } & \multicolumn{3}{|c|}{ RA patients } \\
\hline & Medium & rIL-2† & PHA $\ddagger$ & Medium & rIL-2† & PHA $\ddagger$ \\
\hline 1 & $1278 \pm 177$ & $1384 \pm 276$ & $82458 \pm 2082$ & $658 \pm 104$ & $673 \pm 33$ & $60527 \pm 2940$ \\
\hline 2 & $382 \pm 35$ & $429 \pm 112$ & $76890 \pm 2581$ & $530 \pm 16$ & $321 \pm 106$ & $87530 \pm 1502$ \\
\hline 3 & $1064 \pm 328$ & $1198 \pm 409$ & $106614 \pm 3269$ & $1522 \pm 975$ & $613 \pm 112$ & $66701 \pm 3945$ \\
\hline 4 & $824 \pm 211$ & $585 \pm 173$ & $64803 \pm 2948$ & $1443 \pm 561$ & $1491 \pm 598$ & $35003 \pm 1951$ \\
\hline 5 & $687 \pm 80$ & $783 \pm 49$ & $20272 \pm 402$ & $411 \pm 53$ & $381 \pm 59$ & $15509 \pm 1089$ \\
\hline
\end{tabular}

Results are expressed in cpm $\pm \operatorname{SEM}(\mathrm{n}=3)$.

$*[3 \mathrm{H}]$ thymidine incorporation was assessed on day 3 after an $18 \mathrm{~h}$ pulse.

+ rIL-2 concentration was $25 \mathrm{U} / \mathrm{ml}$.

$\ddagger$ PHA concentration was $1 \mu \mathrm{g} / \mathrm{ml}$.

ability to respond to exogenous IL-2. Our data clearly demonstrated that purified rIL-2 is not mitogenic [12], and the difference in IFNgamma production observed between normal and RA lymphocytes can therefore not be explained by a difference in proliferation. Recently, we have shown that diminution of IFN-gamma generation by RA cells was not due to the effects of either chronic inflammatory disease or drug therapy [3]. The IL-2 and IFNgamma defect(s) are complex and may involve multiple cell interactions. Preactivated RA-T cells absorb smaller amounts of IL-2 than control cells suggesting that they have fewer or lessfunctional IL-2 receptors on their surfaces [16, 17]. Exogenous IL-2 failed to normalize the defective AMLR proliferative response in RA patients [1]. IL-2 regulates the subsequent production of IFN-gamma from T-cells [12] and monocytes are not required for its induction [24]. Kasahara et al. [12] have shown that IL-2 acts directly on unstimulated $\mathrm{T}$ cells to induce IFN-gamma production without induction of a mitogenic response. Both natural killer cells and $T$ cells have been shown to produce IFN-gamma in response to IL-2 $[12,13]$. Since our assay system was not designed to detect natural killer cells, we cannot exclude the possibility that IFNgamma was produced by rIL-2 stimulation of these cells. In RA, the production of both lymphokines is down-regulated by monocyte-mediated events $[3,8,9]$. We have previously shown that the diminished EBV-suppressor-factor generation by autologously-activated RA T cells or a $T$ cell subset is related in part to their increased sensitivity to PGE [8]. Lotz et al. have demonstrated that EBV-related $T$ cell defects in RA could be explained on the basis of a monocyte produced IL-1 inhibitor [9]. RA T cells were not detectably defective in their IFN-gamma production when stimulated by allogeneic non- $T$ cells [3] or autologous monocyte-depleted EBVinfected B-cells [9]. Indomethacin treatment of our adherent cell-depleted RA E-rosetting lymphocytes did not correct their diminished responsiveness to exogenous IL-2. Thus, the rIL-2 deficiency of RA-blood T lymphocytes appears to be a distinct cellular defect not directly related to in vitro PGE or IL-1 inhibitor effects. We cannot exclude the possibility that the exposure of lymphocytes to prostaglandins or IL-1 inhibitor in vivo or the presence of inhibitory cells such as in SLE may have affected the RA cell response [25].

Our study has confirmed the deficiency of RA peripheral blood lymphocytes to exogenous IL-2 and has demonstrated an impaired IFN-gamma

TABLE II

Correlation of Percentage Supernatant-mediated Inhibition of EBV-Induced B Cel.t. Proliferation WITH IFN-GAMMA LEVEL AS ASSESSED BY RADIOIMMUNOASSAY

\begin{tabular}{lccc}
\hline Donor* & rIL-2 $\dagger$ & $\begin{array}{c}\text { Percentage } \\
\text { suppressıon } \ddagger\end{array}$ & $\begin{array}{c}\text { IFN-gamma } \\
\text { (U/mI) }\end{array}$ \\
\hline RA 1 & - & 10 & 0 \\
& + & 10 & 0 \\
RA 2 & - & 25 & 2 \\
& + & 16 & 2 \\
Control 1 & - & 0 & 0 \\
& + & 42 & 5.6 \\
Control 2 & - & 6 & 0 \\
& + & 53 & 10.5 \\
Control 3 & - & 8 & 0.25 \\
& + & 91 & 80.5 \\
\hline
\end{tabular}

* T cell supernatants were obtaned after $72 \mathrm{~h}$ of culture. $+2 \times 10^{6}$ E-rosetting lymphocytes were cultured with $(+)$ or without (-) $25 \mathrm{U} / \mathrm{ml} \mathrm{rIl-2}$.

$\ddagger$ Results are expressed as the mean of two determinations of percentage suppression of EBV-induced B cell proliferation compared with control cultures at 10 days post EBV infection as described in Materials and Methods.

$\S$ Data are expressed as the mean of two determinations of JFN-gamma as described in Materials and Methods. 
production by unstimulated RA $\mathrm{T}$ cells in response to rIL-2.

\section{ACKNOWLEDGEMENTS}

We thank A. Eblee and D. Wohlwend (Cytofluorografic Center) for expert technical assistance. We also thank $C$. Irle for helpful comments.

This work was supported by a grant from the Swiss Federal Commission for Research of Rheumatological Diseases and grant No. 3.400.0.86 from the Swiss National Science Foundation (to J.-M.D.).

\section{REFERENCES}

1. Pope RM, McChesney L, Talal N, Fischbach $M$. Characterization of the defective autologous mixed lymphocyte response in rheumatoid arthritis. Arthritis Rheum 1984;27: $1234-44$.

2. Goto M, Zvaifler NJ. Impaired killer cell generation in the autologous mixed leukocyte reaction by rheumatoid arthritis lymphocytes. Arthritis Rheum 1985;28:731-41.

3. Hasler F, Bluestein HG, Zvaifler NJ, Epstein LB. Analysis of the defects responsible for the impaired regulation of Epstein-Barr virus-induced $\mathrm{B}$ cell proliferation by rheumatoid arthritis lymphocytes: I. Diminished gamma interferon production in response to autologous stimulation. J Exp Med 1983; 157:173-88.

4. Slaughter L, Carson DA, Jensen FB, Holbrook T, Vaughan JH. In vitro effects of Epstein-Barr virus on peripheral mononuclear cells from patients with rheumatoid arthritis. J Exp Med 1978;148:1429-34.

5. Alspaugh MA, Jensen FC, Rabin H, Tan EM. Lymphocytes transformed by Epstein-Barr virus: induction of nuclear antigen reactive with antibody in rheumatoid arthritis. $J$ Exp Med 1978;147:1018-27.

6. Bardwick PA, Bluestein HG, Zvaifler NJ, Depper JM, Seegmiller JE. Altered regulation of Epstein-Barr virus induced lymphoblast proliferation in rheumatoid arthritis lymphoid cells. Arthritis Rheum 1980;23:626-32.

7. Tosato G, Steinberg AD, Blaese RM. Defective EBV-specific suppressor T-cell function in rheumatoid arthritis. $N$ Engl $J$ Med 1981;305:1238-43.

8. Hasler F, Bluestein HG, Zvaifler NJ, Epstein LB. Analysis of the defects responsible for the impaired regulation of Epstein-Barr virus-induced $\mathrm{B}$ cell proliferation by rheumatoid arthritis lymphocytes: II. Role of monocytes and the increased sensitivity of rheumatoid arthritis lymphocytes to prostaglandin E. J Immunol 1983;131:768-72.
9. Lotz $\mathrm{M}$, Tsoukas $\mathrm{CD}$, Fong S, Dinarello CA, Carson DA, Vaughan JH. Release of lymphokines after infection with Epstein Barr virus in vitro: II. A monocyte-dependent inhibitor of interleukin 1 downregulates the production of interleukin 2 and interferongamma in rheumatoid arthritis. $J$ Immunol 1986;136:3643-8.

10. Tosato G, Steinberg AD, Yarchoan R, et al. Abnormally elevated frequency of EpsteinBarr virus-infected $B$ cells in the blood of patients with rheumatoid arthritis. J Clin Invest 1984;73:1789-95.

11. Farrar WL, Johnson HM, Farrar JJ. Regulation of the production of immune interferon and cytotoxic $\mathrm{T}$ lymphocytes by interleukin 2. J Immunol 1981;126:1120-5.

12. Kasahara T, Hooks JJ, Dougherty SF, Oppenheim JJ. Interleukin 2-mediated immune interferon (IFN gamma) production by human $\mathrm{T}$ cells and T cell subsets. $J$ Immunol 1983;130:1784-9.

13. Trinchieri G, Matsumoto-Kobayashi M, Clark SC, Seehra J, London L, Perussia B. Response of resting human peripheral blood natural killer cells to interleukin 2. J Exp Med 1984;160:1147-69.

14. Rappaport RS, Dodge GR. Prostaglandin E inhibits the production of human interleukin 2. J Exp Med 1982;155:943-8.

15. Chouaib S, Chatenoud L, Klatzmann D, Fradelizi $D$. The mechanisms of inhibition of human IL 2 production: II. $\mathrm{PGE}_{2}$ induction of suppressor T lymphocytes. $J$ Immunol 1984;132: 1851-7.

16. Miyasaka N, Nakamura T, Russell IJ, Talal N. Interleukin 2 deficiencies in rheumatoid arthritis and systemic lupus erythematosus. Clin Immunol Immunopathol 1984;31:10917.

17. Combe B, Pope RM, Fischbach M, Darnell B, Baron S, Talal N. Interleukin 2 in rheumatoid arthritis: production of and response to interleukin 2 in rheumatoid synovial fluid, synovial tissue and peripheral blood. Clin Exp Immunol 1985;59:520-8.

18. Ropes MW, Bennett GA, Cobb S, Jacox R, Jessar RA. 1958 revision of diagnostic criteria for rheumatoid arthritis. Bull Rheum Dis 1958;9:175-6.

19. Pellegrino MA, Ferrone S, Theofilopoulos AN. Isolation of human T and B lymphocytes by rosette formation with 2-aminoethyl-isothiouronium bromide (AET)-treated sheep red blood cells and with monkey red blood cells. I Immunol Methods 1976;11:273-9.

20. MacDermott RP, Stacey MC. Further characterization of the human autologous mixed leucocyte reaction. I Immunol 1981;126: 729-34. 
21. Chang TW, McKinney S, Liu V, Kung PC, Vilcek J, Le J. Use of monoclonal antibodies as sensitive and specific probes for biologically active human gamma-interferon. Proc Natl Acad Sci USA 1984;81:5219-22.

22. Evequoz V, Betten $F$, Kristensen $F$, et al. Interleukin 2-independent stimulation of rabbit chondrocyte collagenase and prostaglandin $E_{2}$ production by an interleukin 1 like factor. Eur J Immunol 1984;14:490-5.

23. Uchiyama $T$, Broder $S$, Waldmann TA. A monoclonal antibody (anti-Tac) reactive with activated and functionally mature human $\mathrm{T}$ cells: I. Production of anti-Tac monoclonal antibody and distribution of Tac (+) cells. J Immunol 1981;126:1393-7.

24. Lotz M, Tsoukas CD, Fong S, Dinarello CA, Carson DA, Vaughan JH. Release of lymphokines after Epstein Barr virus infection in vitro: I. Sources of and kinetics of production of interferons and interleukins in normal humans. J Immunol 1986;136:363642.

25. Linker-Israeli M, Bakke AC, Quismorio FP, Horwitz DA. Correction of interleukin-2 production in patients with systemic lupus erythematodes by removal of spontaneously activated suppressor cells. J Clin Invest 1985; 75:762-8.

\section{NOTICES}

\section{THIRTY-THIRD ANNUAL MEETING OF THE VIGGO PETERSEN CENTRE: RHEUMATOLOGY UPDATE 1988 \\ President: Prof. S. de Seze}

Organizing Committee: Profs. A. Ryckewaert, M. F. Kahn, D. Kuntz, A. Dryll and Dr. Cl. Guerin. Dates: $17-18$ March 1988.

Venue: Palais des Congrès, Paris.

Further information: Melle C. Moroy, Centre Viggo Petersen, 6 Rue Guy Patin, 75010, Paris.

\section{ROYAL NATIONAL HOSPITAL FOR RHEUMATIC DISEASES: 250TH ANNIVERSARY INTERNATIONAL CONFERENCE ON RHEUMATOLOGY \\ Dates: 14-16 April 1988.}

In 1988 the Royal National Hospital for Rheumatic Diseases will be celebrating its 250th anniversary. The major event of the seven-month programme will be an international conference focusing on both historical aspects and state of the art lectures from world-renowned authorities.

For further information contact: Andrei Calin, MD FRCP, Royal National Hospital for Rheumatic Diseases, Upper Borough Walls, Bath BA1 1RL, UK.

Tel.: (0225) 65941.

\section{INTERNATIONAL SOCIETY FOR PROSTHETICS AND ORTHOTICS SCIENTIFIC MEETING}

Dates: 18-20 April 1988.

Venue: University of Bath.

Further details: Dr. B. McHugh, ISPO Bath 88, National Centre for Training and Education in Prosthetics and Orthotics, University of Strathclyde, Curran Building, 131 St. James Road, Glasgow G4 OLS, UK.

\section{FOURTH MEDITERRANEAN CONGRESS OF RHEUMATOLOGY FIRST MEDITERRANEAN SYMPOSIUM ON BEHÇET'S DISEASE}

Dates: 2-3 June and 4 June 1988.

Venue: Atatürk Cultural Centre, Istanbul, Turkey.

Main topics: Juvenile chronic arthritis, familial Mediterranean fever, amyloidosis associated with rheumatic diseases, vasculitis in Behçet's disease.

Further information: Prof. N. Dilsen, Istanbul Faculty of Medicine, Division of Rheumatology, Capa, Topkapi, Istanbul, Turkey. 


\section{Ridaura}

Prescribing Information. Presentation $\nabla$ 'Ridaura Tiltab' Tablets, PL 0002/0082, each containing $3 \mathrm{mg}$ auranofin. 60 tablets $\mathrm{f} 28.00$. Indications Adults with active progressive meumatoid arthritis when control with non-steroidal anti-inflammatory drugs is inadequate. Dosage for full instructions see Data Sheet Adults only: Initially $3 \mathrm{mg}$ b.d. in the morning and evening or if well tolerated $6 \mathrm{mg}$ with breakfast or evening meal. Treat for minimum of 3-6 months. If response inadequate after 6 months increase to $3 \mathrm{mg}$ td.s; discontinue if response inadequate after further 3 months. Give anti-inflammatory drugs and analgesics as necessary. Contra-indications Necrotizing enterocolitis, pulmonary fibrosis, exfoliative dermatrtis, bone marrow aplasla or other severe blood dyscrasias, progressive renal disease, severe active hepatic disease and systemic lupus erythematosus. Pregnancy or lactation. Precautions Advise patients of potential side effects prior to therapy. Caution in renal impairment, hepatic dysfunction, inflammatory bowel disease, rash, history of bone marrow depression. Contraception mandatory during treatment and for following 6 months. Monitoring: full blood count with differential and platelet count, tests for unnary protein prior to therapy and at least monthly. Chest $X$-ray at least annually. Check for gastrointestinal symptoms, rash, pruritus, stomatitis or metallic taste. Adverse reactions Gastrointestinal symptoms induding diarnoea or loose stools, nausea, abdominal pain. Reduce dosage temporanly, to e.g. $3 \mathrm{mg}$ a day, or stop treatment and start at lower dosage (see Data Sheet). Very rarely ulcerative enterocoltis: stop treatment Rash sometimes with pruritus, stomatitis and oral mucous membrane reactions, alopecia, conjunctivitis and taste disturbances: stop if rash persistent. Blood dyscrasias including leucopenia, granulocytopenia and thrombocytopenia. Very rarely aplastic anaemia or . agranulocytosis. Stop if signs of thrombocytopenia or platelet count below $100,000 / \mathrm{mm}^{3}$. Nephrotic syndrome or less severe glomerular disease with proteinuria, haematuria: stop if proteinuria persistent or dinically significant Rare reports of pulmonary fibrosis. Minor transient changes in liver function. See Data Sheet for further details. Overdosage Expenience limited: one report of encephaolopathy and peripheral neuropathy. Chelatıng agents, e.g. BAL, may be considered. Legal category POM. 13.7.87. Bridge Pharmaceuticals, A Division of Smith Kline \& French Laboratories Limited, a SmithKline Beckman Company Welwyn Garden City, Hertfordshire AL7 1EY. (C) 1987 Smith Kline \& French Laboratories Limited. 'Ridaura' and 'Tittab' are trade marks

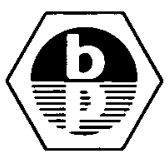




\section{Introducing a favourable benefit/risk ratio for the rheumatoid patient.}

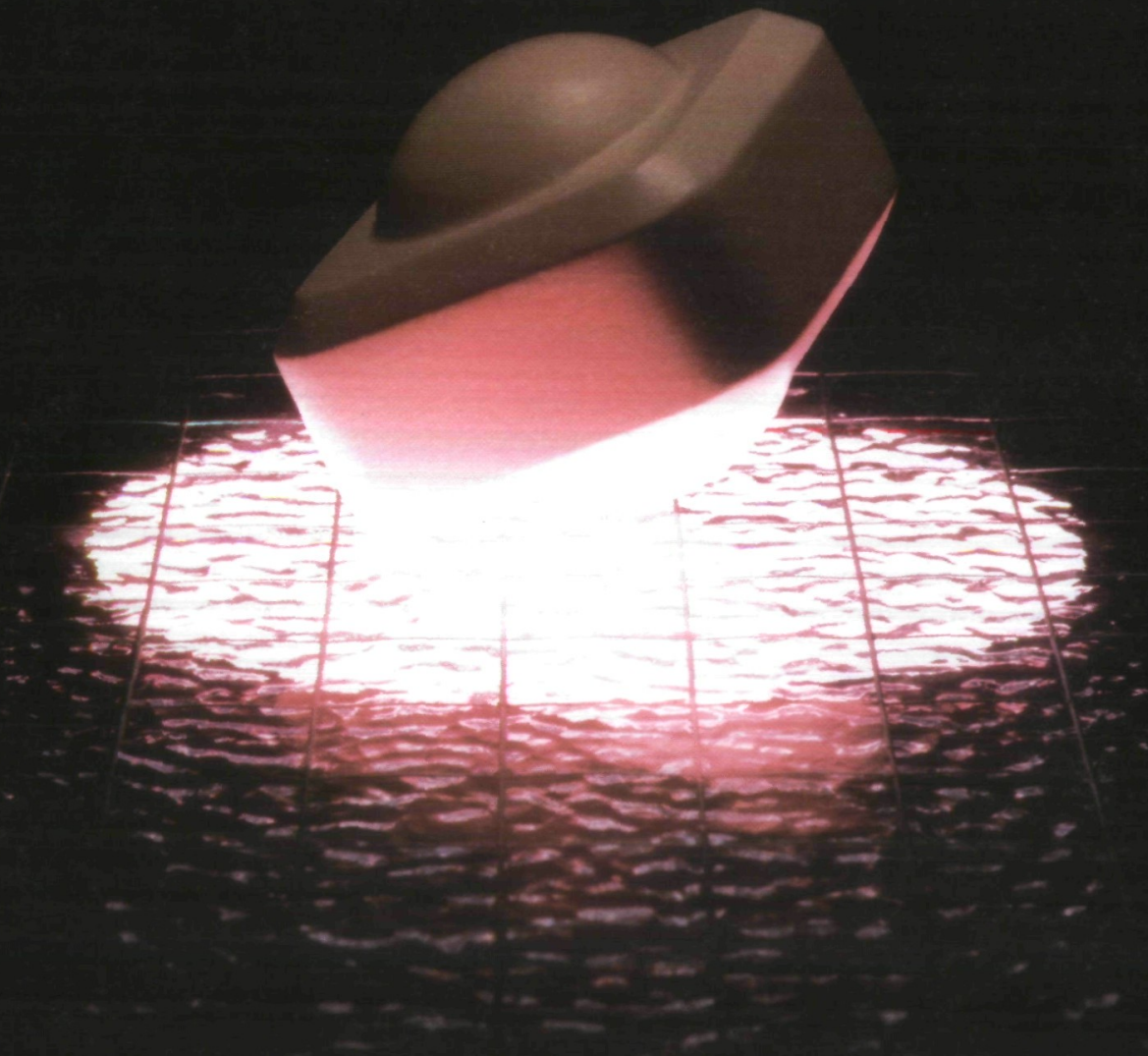

'Ridaura' is a new orally administered gold compound specifically designed for the treatment of rheumatoid arthritis when first-line agents such as NSAIDs have produced an inadequate response.

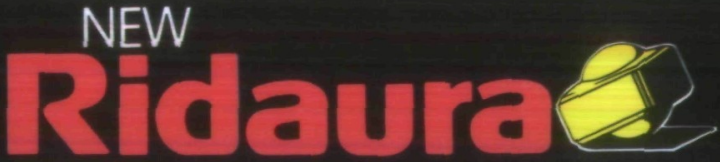

auranofin

A favourable benefit/risk ratio in progressive RA 